\title{
In Vitro Digestibility of Lamtoro Leaves (Leucaena Leucocephala) In Poultry With Gizzard Fluid And Duodenum
}

\author{
Tri Ambarwati ${ }^{1}$, Ali Mursyid Wahyu Mulyono ${ }^{2}$, and Engkus Ainul Yakin ${ }^{2}$ \\ ${ }^{1,2}$ Program Study of Animal Husbandry, Faculty of Agriculture, Universitas Veteran \\ Bangun Nusantara Sukoharjo \\ Corresponding author : alimursyid64@yahoo.com
}

\begin{abstract}
Protein source feed is the feed that has the biggest share in the nutritional needs of livestock. Lamtoro or Leucaena leucocephala is one of the leaf flours that can be used as an alternative feed ingredient for poultry in the tropics. With its abundant availability and does not compete for its needs with humans and has no selling value so that it can minimize consumption costs for poultry. This study aims to determine the effect of fluid from the digestive tract of chickens on the in vitro digestibility measurement of lamtoro leaves. The study used a completely randomized design (CRD) with a unidirectional pattern with 4 treatments and 3 replications. The treatments consisted of $\mathrm{P} 0=$ control, $\mathrm{P} 1$ = gizzard fluid, $\mathrm{P} 2$ = duodenal fluid and $\mathrm{P} 3=$ a mixture of gizzard and duodenal fluid. The results of this study show the average Dry Matter Digestibility Coefficient (\%) for the treatment P0, P1, P2 and P3 respectively; 19.276, 29.089, 20.515 and 28.737. Organic Matter Digestibility Coefficient ; 27.702, 36.313, 24.795 and 35.649. Dissolved Protein Digestibility Coefficient ; 39.777, 53.288, 21.145 and 48.737. The results of the statistical test that the administration of lamtoro leaves showed a significant difference $(\mathrm{P}<0.05)$ on the digestibility coefficient of dry matter, organic matter and dissolved protein. The conclusion is that the use of gizzard liquid is more effective in increasing the in vitro digestibility of lamtoro leaves.
\end{abstract}

Keywords: duodenal fluid, gizzard liquid, in vitro digestibility, lamtoro leave

\section{Introduction}

Protein source feed is the feed that has the biggest share in the nutritional needs of livestock. Protein source feeds are feed ingredients that have a protein content of at least $20 \%$. So far, to meet the protein needs of livestock, the main source of protein from animal feed is fish meal, due to its high protein content and easy to digest (Ikhfa, 2017). The protein content of fish meal is $53.62 \%$ (Sihite, 2013).

Fish meal is a raw material in the manufacture of feed. However, the availability and high price of fish meal are the main obstacles for farmers. This is because it has to be imported from abroad. In addition, the basic ingredients of poultry rations basically compete with human needs (Sulasmi et al., 2013).

To overcome these problems, namely by utilizing non-conventional feed ingredients that are easily found around the community. Lamtoro or Leucaena leucocephala according to (Agbede, 2003 cited by Mandey et al., 2015) is one of the leaf 
flours that can be used as an alternative feed ingredient for poultry in the tropics. With its abundant availability and does not compete for its needs with humans and has no selling value so that it can minimize consumption costs for poultry.

Lamtoro leaves according to (Putri., 2012 cited by Ariyandra R et al., 2017) have a chemical composition of $97.89 \%$ dry matter, $23.83 \%$ crude protein, $31.0509 \%$ nitrogenfree extract (BETN) and $23.5877 \%$ crude fiber, fat $11.68 \%$ and ash $7.73 \%$, while according to (Askar., 1997 cited by Ariyandra et al., 2017) calcium and phosphorus were between $1.90-3.20 \%$ and $0.15-0.35 \%$ of dry matter. The crude protein content of lamtoro leaves is high enough so that it is good for animal feed. According to (Fadhilah., 2004 cited by Faradis., 2004) the crude protein requirement in the ration for broilers in the starter period is $24 \%$ and for the finisher period is $21 \%$.

Mandey et al. (2015) explained that the results of his research in the use of lamtoro leaves up to $20 \%$ can replace some of the basic feed, giving the same response as the basic feed as a control. Although mimosin is a toxic factor that is often mentioned as an obstacle to intensive use, lamtoro has long been used in ruminants and monogastric livestock. Variations in the resulting performance are dependent on the level and nutritional value of the lamtoro used. Lamtoro leaf feed material is expected to be a resource that is available around the clock for broiler feed.

Based on the description above, the authors wish to conduct in vitro digestibility research of lamtoro leaves regarding the digestibility coefficient of dry matter, organic matter and dissolved protein in poultry.

\section{Materials and Methods}

\section{Research Location and Time}

This research was conducted for 4 weeks on February 1 - May 20, 2021 at the Laboratory of the Faculty of Agriculture, University of Veteran Bangun Nusantara Sukoharjo.

\section{Research Materials and Tools Ingredients}

The materials used in this study were lamtoro leaves with young leaves, gizzard and duodenal fluid from broiler chickens, aquadest solution, $0.1 \mathrm{~N} \mathrm{HCl}$ solution and $1 \mathrm{M}$ $\mathrm{NaHCO} 3$.

\section{Tools}

The equipment used in this study were digital scales for weighing lamtoro leaves, plastic for weighing containers for lamtoro leaves, rope for binding, blender for smoothing lamtoro leaves, oven for drying the filtrate, sample spoon for taking lamtoro leaf flour, vortex for stirring gizzard liquid and duodenum, test tube for sample holder, valcon tube as a container for centrifuge, measuring pipette to take the solution, erlenmeyer to mix the solution, label paper to mark each treatment, water bath to incubate the solution and create a constant temperature, whatman 01 paper to filter solution, a petri dish for the sample container, a desiccator for storing dried samples, a crucible for storing samples when heating is too high, a spectrometer to measure the absorbance value of dissolved proteins and a centrifuge to separate the sample from the supernatant. 


\section{Research Methods}

The study used a completely randomized design (CRD) with a unidirectional pattern with 4 treatments and 3 replications. The treatment was the use of liquid from the digestive tract of chickens for in vitro digestibility measurements. The details of the treatment are as follows:

$\mathrm{P} 0=$ no digestive fluid (control)

$\mathrm{P} 1$ = gizzard fluid

$\mathrm{P} 2=$ duodenal fluid

P3 = mixture of gizzard and duodenal fluid

\section{In Vitro Digestibility Measurement Procedures}

P0 Treatment (Control)

1) Three grams of sample of lamtoro leaf flour (TDL) was put into $18 \mathrm{ml}$ of $0.1 \mathrm{~N} \mathrm{HCl}$ solution which was incubated for 45 minutes at $40^{\circ} \mathrm{C}$.

2) Added $9 \mathrm{ml}$ of $1 \mathrm{M} \mathrm{NaHCO} 3$ and incubated for 120 minutes at $40^{\circ} \mathrm{C}$.

3) Centrifuge or filter with whatman paper (the weight of the paper has been weighed first). The filtrate with paper was dried for 24 hours at a temperature of $105^{\circ} \mathrm{C}$. And then weighed again.

4) The supernatant is used immediately or stored at a temperature of $-20^{\circ} \mathrm{C}$ (freezer) if used later

\section{P1 Treatment}

1) Three grams of TDL sample was put into $18 \mathrm{ml}$ of $0.1 \mathrm{~N} \mathrm{HCl}$ solution and gizzard's solution was added which was then incubated for 45 minutes at $40^{\circ} \mathrm{C}$.

2) Added $9 \mathrm{ml}$ of $\mathrm{NaHCO}_{3}$ and incubated for 120 minutes at $40^{\circ} \mathrm{C}$.

3) Centrifuge or filter with whatman paper (the weight of the paper has been weighed first). The filtrate with paper was dried for 24 hours at a temperature of $105^{\circ} \mathrm{C}$. And then weighed again.

4) The supernatant is used immediately or stored at a temperature of $-20^{\circ} \mathrm{C}$ (freezer) if used later.

\section{P2 Treatment}

1) Three grams of TDL sample was put into $18 \mathrm{ml}$ of $0.1 \mathrm{~N} \mathrm{HCl}$ solution and duodenal fluid was added which was then incubated for 45 minutes at $40^{\circ} \mathrm{C}$.

2) Added $9 \mathrm{ml}$ of $\mathrm{NaHCO}_{3}$ and incubated for 120 minutes at $40^{\circ} \mathrm{C}$.

3) Centrifuge or filter with whatman paper (the weight of the paper has been weighed first). The filtrate with paper was dried for 24 hours at a temperature of $105^{\circ} \mathrm{C}$. And then weighed again.

4) The supernatant is used immediately or stored at a temperature of $-20^{\circ} \mathrm{C}$ (freezer) if used later.

\section{P3 Treatment}

1) Three grams of TDL sample was put into $18 \mathrm{ml}$ of $0.1 \mathrm{~N} \mathrm{HCl}$ solution and added gizzard fluid and duodenal fluid which was then incubated for 45 minutes at $40^{\circ} \mathrm{C}$.

2) Added $9 \mathrm{ml}$ of $\mathrm{NaHCO}_{3}$ and incubated for 120 minutes at $40^{\circ} \mathrm{C}$.

3) Centrifuge or filter with whatman paper (the weight of the paper has been weighed first). The filtrate with paper was dried for 24 hours at a temperature of $105^{\circ} \mathrm{C}$. And then weighed again. 
4) The supernatant is used immediately or stored at a temperature of $-20^{\circ} \mathrm{C}$ (freezer) if used later.

\section{Research Variable}

The variables observed in this study were the Dry Matter Digestibility Coefficient (DMDC), Organic Matter Digestibility Coefficient (OMDC) and Dissolved Protein Digestibility Coefficient (DPDC) raw material for lamtoro leaf feed.

\section{Dry Matter Digestibility Coefficient (DMDC)}

DMDC is calculated by the formula:

Information :

$$
\text { DMDC }(\%)=\frac{\text { DM Sample }- \text { DM Residue }}{\text { DM Sample }} \times 100 \%
$$

DMDC : Dry matter digestibility coefficient (\%)

DM Sample : : Sample dry matter (g)

DM Residue : Residual dry matter $(\mathrm{g})$

Organic Matter Digestibility Coefficient (OMDC)

$\mathrm{KCBO}$ is calculated by the formula:

Information :

$$
\text { OMDC }(\%)=\frac{(\mathrm{SOM} \times \mathrm{OMCS})-(\mathrm{ROM} \times \mathrm{ROMC})}{\mathrm{SOM} \times \mathrm{OMCS}} \times 100 \%
$$

OMDC : Organic matter digestibility coefficient (\%)

SOM : Sample organic matter $(\mathrm{g})$

OMCS :Organic matter content of the sample (\%)

ROM : Residual organic matter $(\mathrm{g})$

ROMC : Residual organic matter content $(\%)$

\section{Dissolved Protein Digestibility Coefficient (KCPT)}

$\mathrm{KCPT}$ is calculated by the following formula:

Information :

$$
\operatorname{DPDC}(\%)=\frac{(\mathrm{SDP} \times \mathrm{DPCS})-(\mathrm{RSP} \times \mathrm{RSPC})}{(\mathrm{SDP} \times \mathrm{DPCS})} \times 100 \%
$$

DPDC : Dissolved protein digestibility coefficient (\%)

SDP : Sample dissolved protein $(\mathrm{g})$

DPCS : Dissolved protein content of the sample (\%)

RSP : Residual soluble protein $(\mathrm{g})$

RSPC : Residual soluble protein content (\%)

\section{Data Analysis}

The experimental design used in this study was a completely randomized design (CRD). The data obtained were then analyzed using ANOVA (Analysis of variance). Furthermore, the DMRT (Duncan Multiple Range Test) test was carried out to determine the differences between treatments. Then to calculate the results of the analysis with the help of SPSS software or the Statistical Package for the Social Sciences (Mulyono, 2011). 


\section{Results and Discussion}

\section{Dry Matter Digestibility Coefficient (DMDC)}

Dry matter digestibility was measured to determine the amount of food substances absorbed by the body which was carried out through analysis of the amount of dry matter, both in the ration and in the feces (Ranjhan., 1980 cited by Boangmanalu et al., 2016). The DMDC value is influenced by the level of proportion of feed ingredients in the ration, chemical composition, and protein level (Anggorodi, 1994 cited by Suardin et al., 2014). The results of the study on the effect of treatment of chicken digestive juices with lamtoro leaf flour on DMDC are presented in Table 1.

Table 1. Dry matter digestibility coefficient (DMDC) of lamtoro leaf flour in treatment of chicken digestive juices.

\begin{tabular}{ccccc}
\hline \multirow{2}{*}{ Replication } & \multicolumn{4}{c}{ Treatment } \\
\cline { 2 - 5 } & P0 $(\%)$ & P1 $(\%)$ & P2 $(\%)$ & P3 $(\%)$ \\
\hline 1 & 22.041 & 25.774 & 18.448 & 30.948 \\
2 & 18.636 & 28.281 & 17.788 & 26.474 \\
3 & 17.150 & 33.211 & 25.308 & 28.790 \\
\hline Averages & $19.276^{\mathrm{a}}$ & $29.089^{\mathrm{b}}$ & $20.515^{\mathrm{a}}$ & $28.737^{\mathrm{b}}$ \\
\hline Note $:{ }^{* a b}$ in the treatment column shows a significant difference $(\mathrm{P}<0.05)$. \\
P0 = control ; P1 = Gizzard fluid; P2 = Duodenal fluid; P3 = Mixture of \\
gizzard and duodenal fluid.
\end{tabular}

Based on the results of the analysis of variance Table 1 shows that the digestive juices of chickens with lamtoro leaf flour have a significant effect on DMDC.

The results from Table 1 are that the difference in treatment of lamtoro leaf flour using gizzard liquid and a mixture of gizzard liquid with duodenum can increase the DMDC value. The increase in the average DMDC between P0 and P1 is 9.813\%. The DMDC average could be higher because gizzard liquid contains enzymes that break down nutrients. This is in accordance with the opinion of Jull., (1987) cited by Marlina., (2017) that gizzard functions to destroy food granules and mix them with pepsin and HCL where the protein has begun to be digested. In addition, the use of the duodenum on P2 could not increase the DMDC value compared to the control or P0 due to the ineffective digestive process.

The results of this study are lower than that of Kurniawan's (2019) study that the measurement of DMDC of lamtoro leaf flour with different treatments using the enzymes pepsin and pancreatin can increase by an average of up to $60.69 \%$. This may be due to the effectiveness of the enzyme pepsin and pancreatin itself.

From this research on DMDC measurements, it can be concluded that the use of gizzard liquid has been able to be used in measuring the in vitro digestibility of lamtoro leaves.

\section{Organic Matter Digestibility Coefficient (OMDC)}

The value of the digestibility coefficient of organic matter was obtained through the difference in the initial organic matter content before and after incubation, proportional to the organic matter content before the incubation (Blummel et al., 1997 cited by Ningsi., 2016). Factors that affect OMDC are crude fiber and mineral content of feed ingredients 
(Ismail, 2012 cited by Ningsi., 2016). The results of the study on the effect of treatment of chicken digestive juices with lamtoro leaf flour on OMDC are presented in Table 2.

Table 2. Organic matter digestibility coefficient (OMDC) of lamtoro leaf flour in treatment of chicken digestive juices.

\begin{tabular}{cccrr}
\hline \multirow{2}{*}{ Replication } & \multicolumn{4}{c}{ Treatment } \\
\cline { 2 - 5 } & $\mathrm{P} 0(\%)$ & $\mathrm{P} 1(\%)$ & $\mathrm{P} 2(\%)$ & $\mathrm{P} 3(\%)$ \\
\hline 1 & 30.179 & 33.336 & 22.839 & 37.646 \\
2 & 27.129 & 35.588 & 22.215 & 33.605 \\
3 & 25.798 & 40.016 & 29.330 & 35.697 \\
\hline Averages & $27.702^{\mathrm{a}}$ & $36.313^{\mathrm{b}}$ & $24.795^{\mathrm{a}}$ & $35.649^{\mathrm{b}}$ \\
\hline
\end{tabular}

Note: $a b$ in the treatment column shows a significant difference $(\mathrm{P}<0.05)$.

P0 = control ; P1 = Gizzard fluid; P2 = Duodenal fluid; P3 = Mixture of gizzard and duodenal fluid

Based on the results of the analysis of variance, Table 2 shows that the digestive juices of chicken with lamtoro leaf flour have a significant effect on OMDC.

The results from Table 2 are that the difference in treatment of lamtoro leaf flour using gizzard liquid and a mixture of gizzard liquid with duodenum can increase the OMDC value. The increase in the average OMDC between P0 and P1 is $8.611 \%$. The OMDC average could be higher because gizzard liquid contains enzymes that can break down nutrients.

Table 2 shows that the OMDC analysis has a mean of $31.115 \%$. With a standard deviation of below $10 \%$, it means that the feed ingredients have good quality. In addition, the OMDC value of lamtoro leaf flour was obtained with an average of $31.115 \%$, which value was not much different from the average DMDC result of $24.404 \%$.

According to Kurniawan (2019) the measurement of OMDC of lamtoro leaf flour using the enzymes pepsin and pancreatin can increase by an average of up to $60.69 \%$. This study had a higher mean than this study, this could be due to the effectiveness of the pepsin and pancreatin enzymes themselves.

From this study it can be concluded that the use of gizzard liquid can increase the OMDC value so that it can be used in measuring the in vitro digestibility of lamtoro leaves.

\section{Dissolved Protein Digestibility Coefficient (DPDC)}

Dissolved protein is the percentage of total protein contained in food ingredients that can be extracted or dissolved in water under certain conditions (Andarwulan et al., 2011 cited by Marwah., 2018). DPDC is a measurement of an oligopeptide or amino acids that are easily absorbed by the digestive system (Purwoko., 2006 cited by Marwah., 2018). The results of the study on the effect of treatment of chicken digestive juices with lamtoro leaf flour on DPDC are presented in Table 3. 
Table 3. Dissolved protein digestibility coefficient (DPDC) of lamtoro leaf flour in treatment of chicken digestive juices.

\begin{tabular}{ccccc}
\hline \multirow{2}{*}{ Replication } & \multicolumn{4}{c}{ Treatment } \\
\cline { 2 - 5 } & $\mathrm{P} 0(\%)$ & $\mathrm{P} 1(\%)$ & $\mathrm{P} 2(\%)$ & $\mathrm{P} 3(\%)$ \\
\hline 1 & 41.840 & 51.105 & 19.095 & 50.327 \\
2 & 39.300 & 52.756 & 18.440 & 47.108 \\
3 & 38.191 & 56.004 & 25.900 & 48.775 \\
\hline Averages & $39.777^{\mathrm{b}}$ & $53.288^{\mathrm{c}}$ & $21.145^{\mathrm{a}}$ & $48.737^{\mathrm{c}}$ \\
\hline Note: $^{\text {abc }}$ in the treatment column shows a significant difference $(\mathrm{P}<0.05)$. \\
P0 = control ; P1 = Gizzard fluid; P2 = Duodenal fluid; P3 = Mixture of gizzard \\
and duodenal fluid.
\end{tabular}

The results from Table 3 are the differences in treatment of lamtoro leaf flour using gizzard liquid and a mixture of gizzard liquid with duodenum can increase the DPDC value. The increase in the average DPDC value between P0 and P1 is $13.511 \%$. The DPDC average could be higher because gizzard liquid contains enzymes that can break down nutrients.

From this study it can be concluded that the use of gizzard liquid can increase the DPDC value so that it can be used in measuring the in vitro digestibility of lamtoro leaves.

\section{Conclusion}

Based on the results and discussion above, this study can be concluded that the use of gizzard liquid is more effective in increasing the in vitro digestibility of lamtoro leaves. In the digestibility measurement, the dry matter digestibility coefficient (DMDC) was $29.089 \%$, the organic matter digestibility coefficient (OMDC) was $36.313 \%$ and the dissolved protein digestibility coefficient (DPDC) was $53.288 \%$.

\section{References}

Ariyandra Ariyandra R., Agustono dan Satyantini W. H. 2017. Subtitusi Fermentasi Daun Lamtoro (Leucaena leucocephala) pada Pakan Udang Vaname (Litopenaeus vannamei) terhadap Retensi Potein dan Energi. Journal of Aquaculture Science. 1 (1) : 10-18.

Boangmanalu R, Wahyuni T H dan Sayed Umar. 2016. Kecernaan Bahan Kering, Bahan Organik dan Protein Kasar Ransum Yang Mengandung Tepung 2017Limbah Ikan Gabus Pasir (Butis amboinensis) Sebagai Substitusi Tepung Ikan Pada Broiler. Jurnal Peternakan Integratif. 4 (3) : 329-340.

Faradis H. A. 2009. Evaluasi Kecukupan Nutrien Pada Ransum Ayam Broiler di Peternakan CV. Perdana Putra Chicken Bogor. Universitas Diponegoro Semarang. Ikhfa. 2017. Pengaruh Komposisi Media Terhadap Produksi Cacing Tanah (Lumbricus Rubellus) Untuk Bahan Pakan Sumber Protein. Skripsi. Universitas Andalas, Padang.

Kurniawan J. 2019. Kecernaan In Vitro Daun Lamtoro (Leucaena Leucocephala) Pada Ternak Unggas. Skripsi. Universitas Veteran Bangun Nusantara, Sukoharjo. 
Mandey Jet S, N. J. Kumajas, J. R. Leke dan M. N. Regar. 2015. Manfaat Daun Lamtoro (Leucaena Leucocephala) Dalam Pakan Ayam Pedaging Diukur Dari Penampilan Produksi. Jurnal Zootek. 35(1):72-77.

Marlina. 2017. Pengaruh Penggunaan Tepung Limbah Jus Jeruk (Citrus Sinensis) Dalam Ransum Terhadap Organ Pencernaan Ayam Broiler. Skripsi. Fakultas Peternakan Universitas Jambi.

Marwah. 2018. Kualitas Fisikokimia Biskuit Pada Berbagai Komposisi Tepung Terigu, Tepung Dangke dan Tepung Sagu. Skripsi. Fakultas Peternakan Universitas Hasanuddin, Makassar.

Mulyono, A.M.W. 2011. Rancangan Percobaan. (1). Kepel Press. Yogyakarta.

Ningsi R. 2016. Kecernaan Bahan Kering Dan Bahan Organik Ransum Basal Campuran Gamal dan Lamtoro Dengan Suplemen Multi Nutrisi Pada Kambing Peranakan Etawa. Skripsi. Fakultas Peternakan Universitas Hasanuddin, Makassar.

Sihite H. H. 2013. Studi Pemanfaatan Limbah Ikan Dari Tempat Pelelangan Ikan (Tpi) dan Pasar Tradisional Nauli Sibolgamenjadi Tepung Ikan Sebagai Bahan Baku Pakan Ternak. Jurnal Teknologi Kimia Unimal. 2 (2) : 43-54.

Suardin, Sandiah N. dan Aka R. 2014. Kecernaan Bahan Kering Dan Bahan Organik Campuran Rumput Mulato (Brachiaria Hybrid.Cv.Mulato) Dengan Jenis Legum Berbeda Menggunakan Cairan Rumen Sapi. Jurnal Ilmu dan Teknologi Peternakan Tropis. 1 (1).

Sulasmi, Sapsuha Y. dan Saelan E. 2013. Pengaruh Penambahan Jenis Tepung Daun Leguminosa Yang Berbeda Terhadap Konsumsi, Pertambahan Bobot Badan dan Konversi Ransum Ayam Broiler. Jurnal Ilmiah Agribisnis Dan Perikanan. 6 (1). 